\title{
Construction of normal human IgE phage antibody li- brary and the screening of the anti-trichosanthin IgE
}

\author{
ZAN Hong, Ming YEH \\ Shanghai Institute of Cell Biology, Chinese Academy of \\ Sciences, Shanghai 200031, China.
}

\begin{abstract}
Allergen specific $\operatorname{IgE}$ response is the major cause of immediate hypersensitivity. However the number of IgEproducing $\mathrm{B}$ cells and the amount of $\mathrm{IgE}$, especially the specific IgE, are so low, it greatly impedes the study of the allergic-specifc antibody responses. Here we report the construction of a normal human IgE combinatorial library. The repertoire of $\mathrm{IgE} \mathrm{VH}$ genes and of $\kappa$ genes were separately amplified from normal human peripheral blood lymphocytes through RT-PCR, and were then constructed to form the phage surface display human Fab(IgEVH) library. A plant protein allergen, trichosanthin(TCS), was used to affinity-enrich and to screen the anti-TCS phage HuFab clones from the library. Human $\operatorname{IgE}(\mathrm{Fab})$ to TCS were detected.
\end{abstract}

Key words: Phage antibody library, human IgE(Fab), human anti-trichosanthin IgE.

\section{INTRODUCTION}

$\mathrm{IgE}$ is the major mediator of immediate hypersensitivity. Analysis of the $\mathrm{V}$ region of allergen-specific IgE is of primary importance for the understanding of allergic responses. The cross-reactivity frequently shown in allergic responses also points to the importance of the study of the antigen recognition structure of IgE molecules[l, 2 ]. However, the amount of $\operatorname{IgE}$ is very low in serum. Even under the condition of allergy, when IgE concentration is significantly increased, the level is still around $\mathrm{ng}-\mu \mathrm{g} / \mathrm{ml}[3]$, while the IgG1 in serum attains $\mathrm{mg} / \mathrm{ml}[4]$. Since the amount of serum $\operatorname{IgE}$, especially the antigen-specific IgE, is so low, it greatly impedes the study of 
$\operatorname{IgE} \mathrm{V}$ genes and antigen-specific IgE repertoire. And the study of IgE responses in human is even more difficult.

The advent of antibody library technology provides an efficient approach to study the molecular profile of in-vivo antibody responses[5], especially the recently developed phage antibody library technology shows more advantages[6, 7]. We intend to use the phage antibody library technology to study allergen-specific IgE responses in human, since it can circumvent the restrictions in studying human responses, and provides us the possibility of studying the structural characteristics of the $\mathrm{V}$ region of minute amount of human $\operatorname{IgE}$ and the mechanism of IgE recognition of allergen. The study of allergen-specific IgE with antibody library technology has not been reported. In human peripheral blood, the percentages of IgE-producing B cells frequently only account for $0.001 \%-0.01 \%$ [8]. Because of the great limitation of cell sources, the establishment of an efficient method to amplify IgE $\mathrm{V}$ region genes is of key importance. In this paper, starting from normal human peripheral blood lymphocytes, we amplify the $\mathrm{V} \varepsilon$ and $\kappa$ genes through RT-PCR and then constructed them to form the phage surface display human Fab $\left(\mathrm{V}_{\varepsilon}\right)$ antibody library. A plant protein allergen, trichosanthin(TCS)[9], was used to affinity-enrich and to screen out the anti-TCS $\operatorname{HuIgE}(\mathrm{Fab})$ clones.

\section{MATERIALS AND METHODS}

\section{Human peripheral blood lymphocytes}

The human peripheral blood lymphocytes were separated through Ficoll gradient from the normal human blood samples provided by Shanghai Blood Center.

\section{Plasmids and bacterial strains}

Vector pHEN1[10], Plasmid pSWlFab(D1.3) and the E. coli strain TG1 were all kindly provided by Dr. G.Winter, MRC, Cambridge. Helper phage M13-VCS was from our laboratory.

\section{Primers}

Human $\mathrm{C} \varepsilon$ primer was designed according to constant region gene of human $\varepsilon$ chain, corresponding to position $646-679 \mathrm{bp}$.

HuC $\varepsilon$ FOR: 5'-GCTGAAGGTTTTGTT $\underline{T C G A C C C A G T C T G T G G A-3 ' ~}$

SalI

VKBACK:5'-GACATTGAGCTCACCCAGTCTCCA-3'

SacI

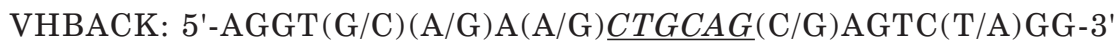

PstI

HuCKFORNot: 5'-GACTTGGGGCCGCAGACTCTCCCCTGTTGAAGCTCTT-3'

NotI

JHFOR:5'-TGAGGAGACGGTGTACCGTGGTCCCTTGGCCCCAG-3'

BstEII

JKFOR:5'-GTTTGATCTCGAGCTTGGTGCC-3

$$
\text { XhoI }
$$




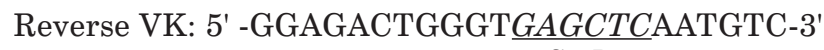 \\ SacI \\ Reverse JH: 5' -GGGACCACGGTCACCCGTCTCCTAC-3' \\ BstEII
}

\title{
Extraction of total $R N A$ and synthesis of cDNA
}

Total RNA was extracted from $5 \times 10^{7}$ lymphocytes according to Chomczynski[11]. The first strand of cDNA was synthesized by primer extention either with light chain constant region primer $\mathrm{HuCKFORNot}$ or with $\varepsilon$ chain constant region primer $\mathrm{HuC} \varepsilon \mathrm{FOR}$.

\section{PCR amplification}

By using $\kappa$ chain cDNA as template and HuCKFORNot and VKBACK as primers, the PCR amplification reactions were performed under the following conditions: $94^{\circ} \mathrm{C}$ for $1 \mathrm{~min}, 57^{\circ} \mathrm{C}$ for $1.5 \mathrm{~min}, 72^{\circ} \mathrm{C}$ for $1.5 \mathrm{~min}$, and cycling for 40 times.

Nested PCR was adopted for the amplification of $\mathrm{V} \varepsilon$ : The first round amplification was run with $\varepsilon$ chain $\mathrm{cDNA}$ as template and $\mathrm{HuC} \varepsilon$ FOR and VHBACK as primers. The PCR was first run for 5 cycles at $94^{\circ} \mathrm{C}$ for $45 \mathrm{sec}, 45^{\circ} \mathrm{C}$ for $1 \mathrm{~min}$, and $72^{\circ} \mathrm{C}$ for $1 \mathrm{~min}$, and then the annealing temperature was raised to $55^{\circ} \mathrm{C}$ and then PCR was further run another 35 cycles. The PCR products were precipitated with ethanol and dissolved in $15 \mu$ l water.

The second round of amplication was performed with the first round PCR products as template and JHFOR and VHBACK as primers. The reaction volume was $50 \mu \mathrm{l}$, including $5 \mu \mathrm{l}$ of the first round PCR products. The PCR was run for 40 cycles at $94^{\circ} \mathrm{C}$ for $45 \mathrm{sec}, 55^{\circ} \mathrm{C}$ for $45 \mathrm{sec}$, and $72^{\circ} \mathrm{C}$ for $1 \mathrm{~min}$.

\section{Reconstruction of vector}

The human CH1 fragment, Fablinker, and some restriction enzyme sites were introduced into vector pHEN1 as Fig 1. The plasmid pSW1Fab(D1.3) was used as template. With Reverse JH and Reverse VK as primers, HuCHI-Fab linker around 450 bp was obtained through PCR amplification. T4 DNA polymerase was used to fill in the recessed end. The fragments were recovered through $2 \%$ low melting point agarose gel electrophoresis. Vector pHEN1 was digested with SacI, filled in the recessed end by T4 DNA polymerase, and dephosphorylated by CIAP. The purified HuCH1-Fab linker fragments were then cloned into pHEN1 and the vector pHEN (HuCHl-linker) was thus constructed.

\section{Construction of phage antibody library}

\section{Construction of $\mathrm{V}_{\varepsilon}$ library:}

The V $\varepsilon$ PCR products were digested with PstI and BstEII. Fragments around 350 bp were gel-purified through $2 \%$ low melting point agarose gel, and cloned into PstI and BstEII sites of vector $\mathrm{pHEN}(\mathrm{HuCHl}-\mathrm{linker}$ ), the vectors were used to transform E.coli TG1 according to Inoye's method[12].

\section{Construction of Fab library:}

The $\kappa$ chain PCR products were digested with SacI and NotI, gel-purified, and then ligated to SacI and NotI digested vector containing the $\mathrm{V} \varepsilon$ gene library, thus forming the Fab library. The ligation products were used to transform E.coli XL1-Blue.

\section{Screening of anti-TCS phage-antibody}

After the E.coli were transformed with the Fab library, the cultures were added with $3 \mathrm{ml}$ of

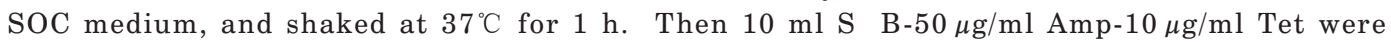

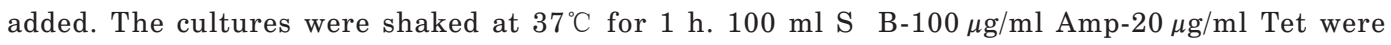




\section{Anti-TCS HuIgE by phage antibody library}

further added, shaking at $37^{\circ} \mathrm{C}$ for another h. After that, helper phages M13-VCS (10 12 p.f.u.) were added. The bacteria were further cultured for $1 \mathrm{~h}$ without shaking, and then kanamycin was added to $70 \mu \mathrm{g} / \mathrm{ml}$. The cultures were shaked for $18-20 \mathrm{~h}$. The released phages were precipitated with 20\% PEG-2.5 $M$ NaC1 for 3 times and then suspended in $3 \mathrm{ml}$ of PBS-1\% BSA.
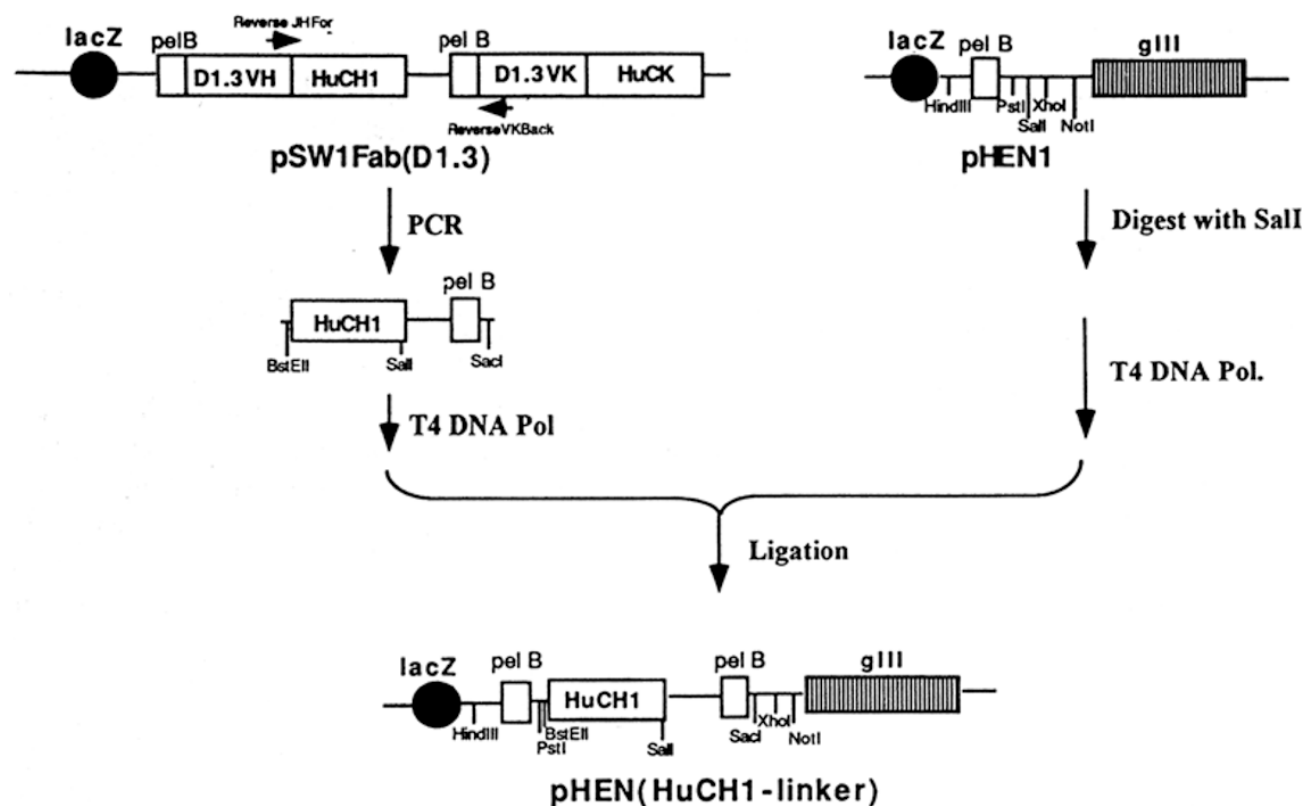

Fig 1. Construction of Vector pHEN (HuCHl-linker)

To PVC tube, TCS (Jin-San Pharmaceutical Factory) was coated at $4{ }^{\circ} \mathrm{C}$ Cover night. The phage suspension was added to the blocked TCS-coated PVC tubes and put in room temperature for $2 \mathrm{~h}$. Then the tubes were thoroughly washed with PBS, PBS-0.1\% Tween 20, and further PBS sequentially. $0.8 \mathrm{ml}$ of $100 \mathrm{~m} M$ triethylamine was used to elute the bound phage particles. The eluates were neutralized with $0.4 \mathrm{ml}$ of $1.0 \mathrm{M}$ Tris-HC1 ( $\mathrm{pH} 7.4)$. The eluted phages were used to transfect $10 \mathrm{ml}$ freshly prepared XL1-Blue $\left(\mathrm{O} \mathrm{D}_{600}=0.8\right)$ at standstill for $45 \mathrm{~min}$. Then $20 \mathrm{ml}$ $\mathrm{S} \quad \mathrm{B}-50 \mu \mathrm{g} / \mathrm{ml} \mathrm{Amp}-10 \mu \mathrm{g} / \mathrm{ml}$ Tet were added, and the cultures were shaked at $37^{\circ} \mathrm{C}$ for $1 \mathrm{~h}$. The above procedures, amplification-antigen adsorption-elution, were repeated for 3 times. And the eluted phages were used to infect E coli XL1-Blue plated on 2YT-Amp-Tet plate.

\section{Phage-ELISA screening}

48 clones randomly selected from the colonies which had gone through four rounds of enrichment were inoculated respectively into $3 \mathrm{ml} \mathrm{LB}$ medium containing $100 \mu \mathrm{g} / \mathrm{ml} \mathrm{Amp}$ and cultured at $37^{\circ} \mathrm{C}$ to $\mathrm{O} . \mathrm{D}_{600}=0.4$. Helper phages were added according to the ratio of bacteria : phage $=20: 1$. They were continued to be cultured for $1 \mathrm{~h}$, and then kanamycin $(70 \mu \mathrm{g} / \mathrm{ml})$ was added. They were further cultured for $18 \mathrm{~h}$. The phage particles were collected through precipitation with PEG and $\mathrm{NaC} 1$ for 2 times, and suspended in $200 \mu 1 \mathrm{PBS}-1 \%$ BSA.

The ELISA plate was coated with TCS and blocked with PBS-1\% BSA. The phage suspension was added, and incubated at $37^{\circ} \mathrm{C}$ for $1 \mathrm{~h}$. Then the plate was washed with PBS-Tween and rabbit anti-M13 antiserum (prepared in our lab) was added. The plate was further incubated at $37^{\circ} \mathrm{C}$ for $1 \mathrm{~h}$. After washing peroxidase labeled goat anti-rabbit Ig antibodies (Bio Rad) were added. After incubation at $37^{\circ} \mathrm{C}$ for $1 \mathrm{~h}$, the substrate $\mathrm{TMB}-\mathrm{H}_{2} \mathrm{O}_{2}$ was added. 
For the competitive binding inhibition ELISA assay, the positive phage clones detected by ELISA were first suspended in PBS-3\% BSA containing $1 \mathrm{mg} / \mathrm{ml}$ TCS or TT (tetanus toxoid, Shanghai Biological Products Institute) at room temperature for $2 \mathrm{~h}$, and then ELISA was carried out as above. The Inhibition Percentage (\%) was calculated as follows,

$$
\text { Inhibition Percentage }(\%)=\left(1-\frac{\text { OD value with inhibitor }}{\text { OD value without inhibitor }}\right) \times 100 \%
$$

\section{RESULTS}

\section{$P C R$ amplification}

The $\kappa$ genes were amplified through RT-PCR. The specifically amplified $650 \mathrm{bp}$ band can be seen in Fig 2 . As for the $\varepsilon$ chain genes, after the first round amplification, the band of $\mathrm{Fd}$ gene fragments with the predicted size did not shown after electrophoresis. Only after the second round amplification, the specifically amplified $350 \mathrm{bp}$ band of $V \varepsilon$ was shown. While in case of the first round amplification with VHBACK- HuIgFOR or VHBACK-HuIg MFOR as primers and cDNA synthesized by human $\mathrm{C} \varepsilon$ primer as template, after two rounds of amplification the predicted $350 \mathrm{bp}$ band could not be seen. It thus indicated that the $\mathrm{V} \varepsilon$ fragments obtained were not resulted from the contamination of $\mathrm{VH}$ genes from other Ig classes.

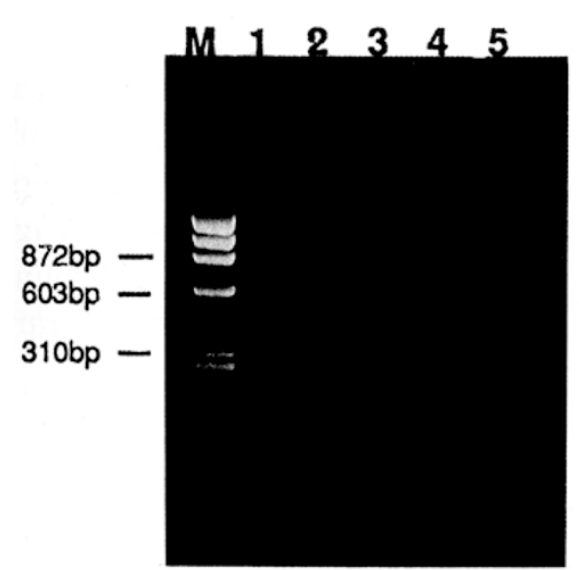

Fig 2. Results of PCR amplification of antibody gene fragments M. Phix 174 RF DNA/HaeIII;

1. $\mathrm{Hu} \kappa$ chain; 2. $\mathrm{Hu} \mathrm{V} \varepsilon$;

3. Nested PCR products (VHBACK and HuIgGFOR used as primers in first round); 4. Nested PCR products (VHBACK and HuIgMFOR used as primers in first round); 5 . $\mathrm{Hu} \varepsilon \mathrm{Fd}$

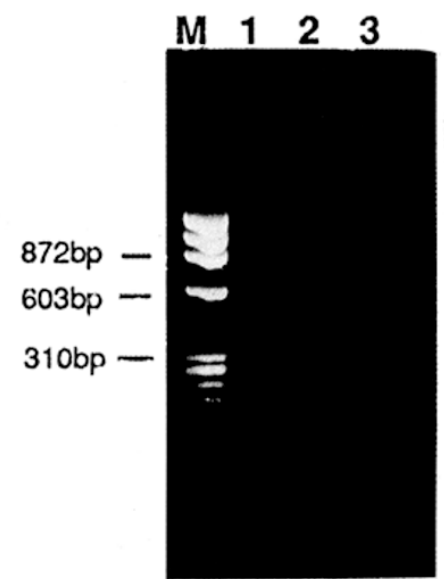

Fig 3. Results of amplification of $\mathrm{V} \varepsilon$ genes through RT-PCR from different amount of RNA

M. Phix 174 RF DNA/HaeIII; 1 - 3.

$\mathrm{V} \varepsilon$ PCR products generated from RNA of $10^{7}$. (1) $10^{6}$; (2) $10^{5}$;

(3) human PBL. 
Anti-TCS HuIgE by phage antibody library

Fig 3 shows the results of the amplification of $\mathrm{V} \varepsilon$ fragments from different quantity of RNA corresponding to RNA from different numbers of cells. It can be seen that from $10^{5}-10^{7}$ cell RNA the $\mathrm{V} \varepsilon$ gene fragments could all be amplified.

\section{The reconstruction of vector}

The PCR amplified fragments, HuCH1-Fab linker, were inserted into vector pHEN1. The pHEN(HuCH1-linker) clones with sense insertion were obtained, since fragments around 450 bp could be detected after digestion with either PstI and SacI or XhoI and BstEII, but not with PstI and BstEII or XhoI and SacI (Fig 4).

Fig 4. Identification of $\mathrm{pHEN}(\mathrm{HuCHl}$-linker) by enzyme digestion

M. $\lambda /$ HindIII, EcoRI

1. $\mathrm{pHEN}(\mathrm{HuCHl}$-linker)/PstI, SacI

2. $\mathrm{pHEN}(\mathrm{HuCHl}$-linker)/PstI, BstEII

3. $\mathrm{pHEN}(\mathrm{HuCHl}$-linker)/BstEII, XhoI

4. $\mathrm{pHEN}(\mathrm{HuCHl}$-linker $) / \mathrm{XhoI}$, SacI

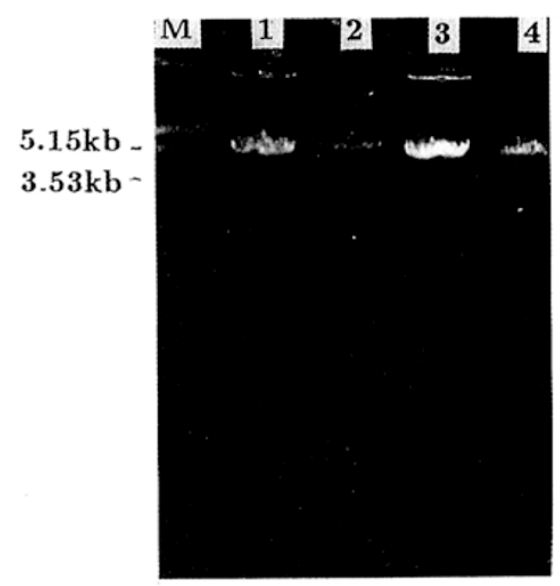

The construction of $V \varepsilon$ library

The obtained $V \varepsilon$ gene fragments were cloned to $\mathrm{pHEN}(\mathrm{HuCH} 1$-linker) and was thus established the humanV $\varepsilon$ library. The capacity of the library was $2 \times 10^{5}$. Using vectors from $V \varepsilon$ library as templates and VHBACK and JHFOR as primers, through PCR amplification the $350 \mathrm{bp}$ band could be shown. Furthermore through digestion of the vectors of the library with PstI and BstEII, fragments of around $350 \mathrm{bp}$ could be cut out (data not shown). It indicates that the constructed library contains $\mathrm{V} \varepsilon$ genes.

\section{The construction of phage $\mathrm{HuFab}\left(V_{\varepsilon}\right)$ library}

The vectors of $\mathrm{V} \varepsilon$ library were digested with SacI and NotI and recovered through $0.8 \%$ low melting point agarose gel electrophoresis. The recovered products were ligated with $k$ gene PCR products digested with SacI and NotI and they were used to transform XL1-Blue, and was thus established the phage $\mathrm{HuFab}(\mathrm{V} \varepsilon)$ Library. The capacity of this library was $5 \times 10^{5}$. Seven clones were randomly selected and amplified with VHBACK and JKFOR primers. All of them were of $1.2 \mathrm{~Kb}$ (Fig 5). It indicated that the Fab genes were inserted.

\section{The Screening of anti-TCS human Fab(VE) clones}

Through 4 rounds of antigen adsorption-elution-amplification, 48 phage clones 
were selected. After purification with PEG the phage antibody clones were subjected to ELISA assay. Two anti-TCS clones were detected (Tab 1). The two clones show higher binding value to TCS, though not very significant. Perhaps it is due to the library being constructed from normal but not TCS-immunized human lymphocytes.

One clone was further analyzed with competitve binding inhibition assay. From Fig 6 , it can be seen the binding could be significantly inhibited by soluble TCS. It thus signified the antigen specificity of the clone selected.

Tab 1. Antigen binding activity of phage HuIgE-Fab clones

\begin{tabular}{cc}
\hline Clones & OD450 $(\mathrm{X} \pm \mathrm{SD})$ \\
$\mathrm{n}=4$ \\
\hline 1 & $0.381 \pm 0.028$ \\
2 & $0.348 \pm 0.021$ \\
Control & $0.178 \pm 0.019$ \\
$\mathrm{pHEN}($ HuCH1-linker $)$ & \\
\hline
\end{tabular}

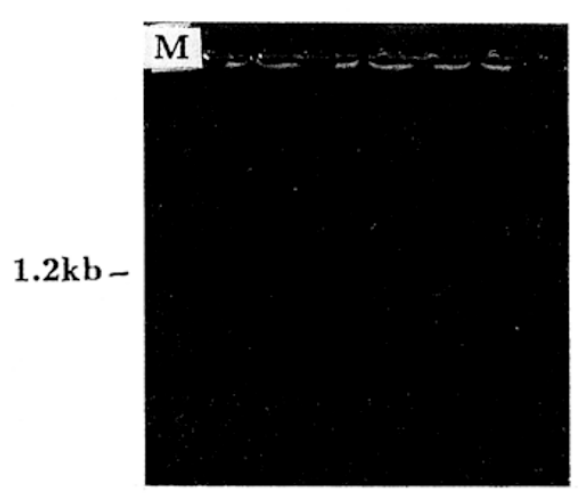

Fig 5. PCR identification of phage HuIgEFab library

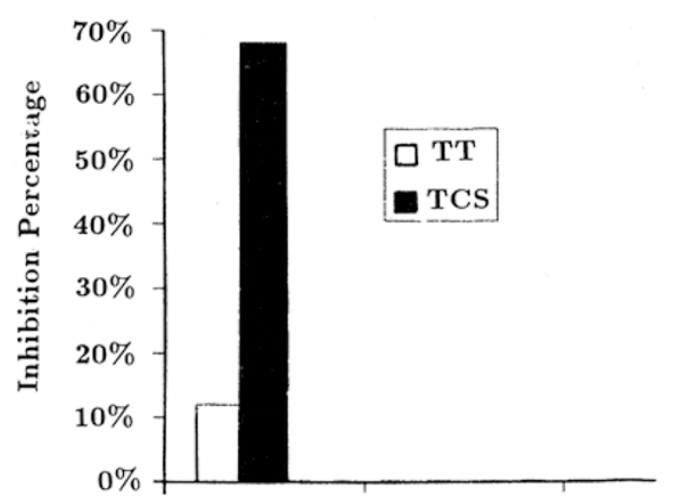

Fig 6. Antigen specificity of the human phage HuIgE-Fab 1 clone by competitive binding inhibition assay

\section{DISCUSSION}

Since the number of IgE-B cells in the peripheral blood lymphocytes is very small, hence the percentage of $\varepsilon$ chain mRNA in the total RNA is also extremely small. It is the reason why we adopted nested PCR during amplification of $\mathrm{V} \varepsilon$ gene. That is using IgE constant region 3 ' end primer and $\mathrm{V}$ region 5 ' end primer during the first round amplification, and then using $\mathrm{JH}$ region primer and $\mathrm{V}$ region $5^{\prime}$ end primer in the second round amplification. In this way we could get sufficient amount of $V \varepsilon$ 
gene fragments to construct IgE library, and it also has the advantage of avoiding non-specific amplification.

The light chain genes and the heavy chain genes are randomly assembled together during the construction of the antibody library. Therefore the study of the antigenspecific IgE profile in the present antibody library technology may not reflect the original $\mathrm{V} \varepsilon-\mathrm{V} \kappa$ pairing in the in-vivo IgE repertoire. However, the $\mathrm{V}_{\kappa}$ of light chain in the Fab screened out from the library is at least to be able to combine with the $\mathrm{V} \varepsilon$ to form the antigen specific combining site. In this sense the $\kappa$ chain in Fab may also reflect the characteristics of the VL used in anti-TCS IgE.

During amplification of $\mathrm{V} \varepsilon$ genes, five normal human blood samples from the blood center have been tried. Only in one of them, the amplified fragments could be satisfactorily obtained. We wonder whether the $\operatorname{IgE}$ level was higher in that person. However, in the Blood Center all donors have been carefully examined before qualified blood samples are drawn. It may be due to other reasons that we have not realized yet, either technically or physiologically.

Due to the small capacity of human $V \varepsilon$ repertoire, in order to offer more light chains to combine with $\mathrm{Fd}$ fragments containing $\mathrm{V} \varepsilon$. During the construction of the library, we first cloned the $V \varepsilon$ genes. In this way we will be able to use a scanty amount of $V \varepsilon$ fragments to construct as possible the biggest library.

For specific amplification of $\varepsilon$ genes from human peripheral blood, if it is required to separate or enrich the small number of IgE-B cells first and then to extract RNA from the isolated B cells to perform RT-PCR, it would be a a difficult and laborious task. Here we have directly amplified $V \varepsilon$ fragments from total RNA of PBL lymphocytes and have tried to amplify $V \varepsilon$ from different amount of RNA. Our results showed that it is possible to amplify even from RNA of $10^{5}$ cells. Our present results indicate that now it would be possible to study IgE $\mathrm{V}$ region with even small quantity of clinical samples.

Our results also point to the possible presence of IgE-B cells to TCS in normal human peripheral blood lymphocytes. The structural characteristics of their V regions and the immunological significance of their existence need further investigation.

\section{ACKNOWLEDGMENT}

The work was supported by the Graduate Grant and Director Grant of Shanghai Institute of Cell Biology, Chinese Academy of Sciences, and also supported by the World Laboratory. We are most grateful to the generous and great help from Dr. Greg Winter in Cambridge, England.

\section{REFERENCES}

[1] Varga JM, Kalchschmid G, Klein GF, Fritsch P. Mechanism of allergic cross-reactions: Multispecific binding of ligands to a mouse monoclonal anti-DNP IgE antibody. Mol Immunol 1991; 28:641. 


\section{Zan $\mathrm{H}$ and $\mathrm{M}$ Yeh}

[2] Long A, MacDonald M, Schwartz R, Ohman J. Selective V gene use in IgE of Atopic Dermatitis. J Allergy Clin Immunol 1994; 93:220.

[3] Gascan H, Gauchat JF, de Waal Malefyt R, Schneider P, Yssel H, deVries JE. Regulation of human IgE synthesis. Clin Exp Allergy 1991; 21 suppl 1:162.

[4] Schur PH. IgG subclasses - a review. Ann Allergy 1987; 58:89.

[5] Barbas CF, Collet TA, Amberg W, Roben P, Binley JM, Hoekstra D. Molecular profile of an antibody respones to HIV-1 as probed by combinatorial libraries. J Mol Biol 1993; 230:812.

[6] Chiswell DJ, McCafferty J. Phage antibodies: will new "coliclonal" antibodies replace monoclonal antibodies? TIBTECH 1992; 10:80.

[7] Clackson T, Hoogenboom HR, Griffiths AD, Winter G. Making antibody fragments using phage display libraries. Nature 1991; 352:624.

[8] Sparholt SH, Barington T, Sehon C. Detection of B-lymphocytes secreting antibodies to Dermatophaoides antigens. Clin Exp Allergy 1991; 21:85.

[9] Ji YY, Yang CY, Yeh M. The influence of trichosanthin in the induction of IgE responses to ovalbumin under adjuvant-free condition. Cell Res 1995; 5:67.

[10] Hoogenboom HR,Griffiths AD, Johnson KS, Chiswell DJ, Hudson P, Winter G. Multi-subunit proteins on the surface of filamentous phage: methodologies for displaying antibody (Fab) heavy and light chains. Nucl Acid Res 1991; 19:4133.

[11] Chomczynski P, Sacchi N. Single step method of RNA isolation by acid guanidinium thiocyanatephenol-chloroform extraction. Anal Biochem 1987; 162:156.

[12] Inoye H, Nojima H, Okayama H. High efficiency transformation of E.coli with plasmids. Gene 1990; 96:28.

Received 3-4-1996. Revised 11-6-1996. Accepted 12-6-1996. 